\title{
Environmental concerns about the massive use of disinfectants during COVID-19 pandemic: an overview on aquatic toxicity
}

\author{
Cruz, J.V.1,2; Magalhâes, W.L.E. ${ }^{3}$; Cademartori, P.H.G. ${ }^{4,5}$; Dorta D. J. ${ }^{6,7}$; \\ De Oliveira, D.P. ${ }^{1,7} \&$ Leme, D.M., ${ }^{2,7 * *}$ \\ ${ }^{1}$ School of Pharmaceutical Sciences of Ribeirão Preto, University of São Paulo. \\ ${ }^{2}$ Department of Genetics, Federal University of Paraná. \\ ${ }^{3}$ Embrapa Florestas. \\ ${ }^{4}$ Graduate Program in Engineering and Science of Materials - PIPE, Federal University of Paraná. \\ ${ }^{5}$ Department of Engineering and Forestry Technology, Federal University of Paraná. \\ ${ }^{6}$ Departament of Chemistry, University of São Paulo. \\ ${ }^{7}$ National Institute for Alternative Technologies of Detection, Toxicological Evaluation and Removal \\ of Micropollutants and Radioactives (INCT-DATREM).
}

Received September 08, 2019; Accept December 16, 2021

\begin{abstract}
Many public health measures to mitigate the spread of SARS-CoV-2 were adopted worldwide, and particularly to the environmental measure of regular cleaning and disinfection of surfaces, the increased use of disinfectant products raises environmental concerns. Quaternary ammonium compounds (QACs), povidone-iodine (PVP-I), chloroxylenol (PCMX) and chlorhexidine (CHX) are the active ingredients of most disinfectant products due to their effectiveness against various microbiological agents. Although presenting antimicrobial efficacy, these biocides have been associated with impacts on aquatic life. For instance, QACs can induce toxicity to Aliivibrio fischeri and fish (different species). Gill and liver damages are verified in Cyprinus carpio after exposure to PVP-I. CHX induces toxic effects on algae, crustaceans, and fish embryos. PCMX can induce genotoxicity to rainbow trout and malformations on zebrafish embryos, as well as it can reduce the reproduction rate of Caenorhabditis elegans. Thus, the potential to cause negative consequences on human and environmental health has resulted in activities from the U.S. and European agencies to favor the use of safer and greener disinfectant products during the COVID-19 pandemic. This review article summarizes the main findings on the impacts of disinfectants (the most used) on aquatic life. This information may help prioritize disinfectants with lower impacts on the aquatic environment for daily use, and especially for high-frequency use as verified in the COVID-19 pandemic. Furthermore, this review may help identify knowledge gaps on the aquatic hazard of disinfectants, which may drive future studies on this matter and, lastly, contribute to the development of sustainable products.
\end{abstract}

Keywords: SARS-CoV-2; Quaternary Ammonium Compounds; Aquatic Organisms; Greener Alternatives.

\section{INTRODUCTION}

The emergence of the new coronavirus SARS-CoV-2 (Severe Acute Respiratory Syndrome Coronavirus 2), family Coronaviridae, has become a worldwide concern: it infects humans and can have severe consequences to human health. SARS-CoV-2 was first identified in December 2019 in Wuhan, China; the World Health Organization (WHO) 
declared a world pandemic on March 11, 2020 (de Bruin et al., 2020). After SARS-CoV (Severe Acute Respiratory Syndrome Coronavirus) in 2002 and MERS-CoV (Middle East Respiratory Syndrome Coronavirus) in 2013, this is the third time a coronavirus has transposed species and infected humans. The disease caused by SARS-CoV-2 is called COVID-19 (Coronavirus Disease 2019) (Perlman, 2020), and has led to a high rate of hospitalization and deaths, producing a significant impact on public health (Pereira, 2020). On September 8, 2021, over 221 million cases of COVID-19 had been reported, and 4.5 million deaths had been registered (WHO, 2021).

Like SARS-CoV and MERS-CoV, SARS-CoV-2 belongs to the $\beta$-coronavirus genus. It is an enveloped virus with a diameter of $65-125 \mathrm{~nm}$ and single RNA strands. It has four structural proteins: spike (S) glycoprotein, small envelope (E) glycoprotein, membrane (M) glycoprotein, and nucleocapsid (N) glycoprotein. S glycoprotein, a transmembrane protein, binds to the angiotensin-converting enzyme 2 (ECA2) receptor, thus mediating SARS-CoV-2 entry in the cell. SARSCoV-2 incubation lasts between 2 and 14 days. Vaccines have been developed and distributed; on September 5, 2021, approximately 5.3 billion vaccine doses were administered (WHO, 2021). However, new SARS-CoV-2 variants are being reported and it will be required some time for an expressive percentage of the population to be vaccinated; in this context, non-pharmaceutical interventions (NPI) are still necessary to avoid the increase in SARS-CoV-2 transmission.

RNA viruses are usually less stable than DNA viruses. However, studies have shown that SARS-CoV-2 is highly stable on different surfaces, which makes surface disinfection an essential measure to control its spread. Van Doremalen et al. (2020) compared SARS-CoV and SARS-CoV-2 and found that SARS-CoV-2 in an aerosol formulation is viable for up to 72 hours after the application on different surfaces. Authors also showed that it is more stable on plastic and stainless steel, with a half-life of 6.8 and 5.6 hours, respectively, similar to SARS-CoV (van Doremalen et al., 2020). Nevertheless, SARS-CoV has longer viability on a copper surface than SARS-CoV-2 (eight and four hours, respectively). On cardboard, SARS-CoV and SARS-CoV-2 remain viable for 8 and 24 hours, respectively (van Doremalen et al., 2020). Another study showed that SARS-CoV-2 is more stable on soft surfaces and can be detected for up to seven days in surgical masks, plastic, and stainless steel and four days in a glass when $5 \mu \mathrm{L}$ of virus culture was pipetted in these surfaces (Chin et al., 2020). The results found in both studies may be distinct due to their different methodology.

Furthermore, a study conducted by Vicente and colleagues (2021) detected SARS-CoV-2 RNA in 35 environmental surfaces from a total of 711. Samples were collected from July 2020 to December 2020 and were obtained from primary care units, emergency care units, COVID-19 ward units and intensive care units. Viral RNA was detected on nondisposable instruments (dental reflectors, dental chairs), which were previously disinfected, and on personal items (pens, stamps, notebooks). In primary care units, the frequency of surface contamination was higher than in hospital settings (Vicente et al., 2021).

Temperature also affects SARS-CoV-2 viability. A dried culture of the new coronavirus is viable for 3 to 5 days at room temperature $\left(20 \pm 5{ }^{\circ} \mathrm{C}\right), 14$ days at $4{ }^{\circ} \mathrm{C}$, and 1 day at $37^{\circ} \mathrm{C}$. In a solution of minimal essential medium containing $10 \%$ fetal bovine serum, SARS-CoV-2 is viable for 7 days at room temperature, 14 days at $4{ }^{\circ} \mathrm{C}$, and 1 to 2 days at $37^{\circ} \mathrm{C}$ (Chan et al., 2020). However, the relevance of these studies for a reallife scenario of exposure to the novel coronavirus has been questioned mainly because the above studies were performed in controlled laboratory conditions with large densities of the virus per sample (Goldman, 2020).

Thus, despite few authors having questioned transmission through fomites, this measure is still among the NPI measures currently adopted by governmental bodies worldwide (e.g., UK, Brazil, EU, USA) to control SARS-CoV-2 transmission in hospitals and non-hospital settings. In addition, disinfection and cleaning surfaces have shown effectiveness in controlling other respiratory viruses, being an NPI measure of relevance for controlling respiratory diseases (Bloomfield et al., 2007). Disinfection became standard practice for preventing SARSCoV-2 in household and hospital settings (Nabi et al., 2020).

Disinfection is an efficient tool to prevent the spread of pathogenic microorganisms; however, ingredients of disinfectant products, such as active ingredients, may pose hazard to aquatic organisms. For instance, quaternary ammonium compounds (QACs) present toxicity to algae with $\mathrm{EC}_{50} 96 \mathrm{~h}$ between 0.1 to $1.8 \mathrm{mg} \mathrm{L}^{-1}$, depending on their alkyl chain length. Also, QACs can induce toxic effects (mortality) on rainbow trout; $\mathrm{LC}_{50} 24 \mathrm{~h}$ ranges from 0.6 to $41 \mathrm{mg} \mathrm{L}^{-1}$, and these values increase as increase the alkyl chain length of QACs (Hora et al., 2020). Therefore, scientifically-based protocols for selecting and proper use of disinfectants are available to minimize the negative impact of these ingredients usage (Centers for Disease Control and Prevention, 2013). Usually, QACs, alcohol, aldehyde, hypochlorous acid, sodium hypochlorite, povidone-iodine (PVP-I), chlorhexidine (CHX) and chloroxylenol (PCMX) are the ingredients responsible for virucidal activity (Pradhan et al., 2020).

The United States Environmental Protection Agency (US EPA) offered the Emerging Viral Pathogen guidance to approve disinfectants for use against SARS-CoV-2. The most common active ingredients among the approved disinfectants are QACs (US EPA, 2020a, 2020b), which are widely employed in commercial disinfectant formulations aimed at cleaning and disinfecting hospitals, clinics, and household settings. QACs can inactivate SARS-CoV-2 within 15-30 s of contact in the presence of mucin or bovine serum albumin (BSA) soil load. Thus, the COVID-19 pandemic has caused exposure to QAC-based disinfectants to increase in the last year (Ogilvie et al., 2020; Schrank et al., 2020).

When it comes to avoiding the transmission of pathogens, disinfectants provide good results, but they often leave 
the surface rapidly via evaporation and hand contact. In a pandemic scenario due to a respiratory virus with a high transmissibility rate, different surfaces need to be disinfected more frequently. However, this is not always feasible, mainly in the case of the surfaces of public spaces, such as public transport. In this situation, a long-lasting disinfectant would control transmission more efficiently (US EPA, 2020c). Considering that, US EPA is working on a QAC-based disinfectant that should be effective against SARS-CoV-2 and have a long-lasting effect. QACs are being combined in different types of formulations. To date, US EPA has not conducted experiments with the new coronavirus, but the developed products are promising because they can inactivate the enveloped bacteriophage phi6, a surrogate for SARSCov-2 (US EPA, 2020c, 2020d).

This review article revised the literature on the impacts of QACs and other most used biocides, such as povidone-iodine (PVP-I), chloroxylenol (PCMX), and chlorhexidine (CHX), on the aquatic environment. The review article summarizes data on aquatic toxicity, bioaccumulation and biodegradability of the disinfectants. In addition, the article presents sessions addressing changes in cleaning and disinfection habits from consumers and activities from U.S. and European agencies to promote the use of safer and greener disinfectants during the COVID-19 pandemic.

\section{Literature sources used for this review}

For the literature search, relevant studies were identified through searching the databases Science Direct, PubMed, and Google Scholar using the keywords 'SARS-CoV-2', 'disinfectants', 'quaternary ammonium compounds', 'chlorhexidine', 'povidone-iodine', 'chloroxylenol', 'toxicity', 'aquatic organisms', 'impacts on aquatic environment', 'biodegradability', 'environmental fate', 'wastewater treatment plants' as well as combination thereof. A restriction was made to only select peer-reviewed studies of English language journals, and there was no restriction regarding the date of the publication. Both original and review articles were considered. Information from registration dossiers for a substance available at the European Chemical Agency (ECHA) was also considered for this review article.

\section{Occurrence of biocides in aquatic environments}

Biocides are a group of chemicals that are commonly used as preservatives, antiseptics and disinfectants. Several biocides are high production volume chemicals; thus, they can frequently reach the aquatic environment, and some of them can be adsorbed to sludge and sediment (Östman et al., 2017). The entrance sources of biocides into aquatic environments are diverse, but the hospital and domestic effluent discharges outstand (Zhang et al., 2015).

For instance, a Swedish study showed that QAC was the most abundant biocide found in STPs, and benzalkonium chloride (BAC) was found in sludge at a concentration of $35 \mathrm{ng}$
$\mathrm{L}^{-1}$. CHX was also presented in STPs, being detected in $67 \%$ of the samples, specifically at the incoming sewage water (water and particles). The concentration of CHX in these samples was around $1300 \mathrm{ng} \mathrm{L}^{-1}$; however, this concentration was significantly reduced by $28 \mathrm{ng} \mathrm{L}^{-1}$ after treatment. Although a reduction in $\mathrm{CHX}$ concentration was verified, this was the first occurrence of CHX in treated sewage waters of Sweden. In addition, the Swedish study also demonstrated the presence of CHX in sludge at a concentration of $8900 \mathrm{ng} / \mathrm{g}$ (Östman et al., 2017). The presence of PCMX in surface water in concentrations higher than $100 \mathrm{ng} \mathrm{L}^{-1}$ was already described in the literature; however, it is reported that it is removed to a high extent during wastewater treatment (Kasprzyk-Hordern et al., 2009).

Urban runoff can be another source of biocides' occurrence in aquatic environments. BAC, which is a $\mathrm{QAC}$ used to clean roofs and eliminate lichens, moss and algae, was detected in water samples after the roof cleaning process at high concentration $\left(2.7 \times 10^{-13} \mathrm{mg} \mathrm{L}^{-1}\right)$. This concentration can decrease when the total rainfall is around $280 \mathrm{~mm}$ (Van De Voorde et al., 2012; US EPA, 2006). In addition, BAC was found in sediments of the Hudson River, a river located in U.S., at concentrations ranging from 40 to $8900 \mathrm{ng} \mathrm{g}^{-1}$. Of note, these concentration values were higher than the concentrations of other contaminants (e.g., aluminum and organic carbon). This finding can indicate that the adsorption of QAC into sediments may compromise the effectiveness of wastewater treatment (Li \& Brownawell, 2010).

Although we have presented environmental monitoring studies reporting the environmental occurrence of biocides of relevance for the COVID-19 pandemic, the available information is limited, and efforts are required to improve our understanding of the concentration of these biocides in aquatic environments. This information, together with hazard data, may help better predict the risk of these chemical substances for aquatic life.

\section{Changes in consumers' cleaning and disinfection habits: concerns about cumulative toxicity}

Over the last months, news and market researchers have reported changes in consumers' behavior. A survey conducted by Statista showed that $41 \%$ of males and $49 \%$ of females expect to spend more on disinfectant products because of the COVID-19 pandemic (Statista, 2020).

Household cleaning practices have a greater increase in U.S. than in the United Kingdom (UK) after the first reported case of COVID-19. For instance, $44 \%$ of consumers in the U.S. use disinfectants at home more frequently, while in UK $37 \%$ of consumers have increased the use of these products. Moreover, $18 \%$ and $9 \%$ of US and UK consumers, respectively, have reported stocking up hard surface cleaners in case of shortage. On the other hand, $24 \%$ of UK consumers and $16 \%$ of US consumers have not reported any hard surface cleaning habits changes (Novozymes and Conjoint.ly, 2020).

A report by Nielsen (The Nielsen Company (US), 2020) showed increased proactive health shopping. In Brazil, in the first week after the first case of COVID-19 was reported, the 
use of antiseptics grew by $623 \%$. In Canada, consumption of alcohol-based hand rub and cleaning products increased by $166 \%$ and $15 \%$, respectively, and in the Netherlands and Korea, consumption of soaps increased by levels higher than 200\% (The Nielsen Company (US), 2020).

Although raising awareness of the importance of cleaning and disinfection helps control SARS-CoV-2 transmission, the consumers' behavior in using these products may cause human health problems and environmental impacts. In the U.S., $42 \%$ of consumers do not follow label instructions during the use of disinfectant products. The ideal procedure is to clean the surface before applying the disinfectant product, letting it air-dry. QACs are commonly found in cleaning and disinfecting products. Incorrect use of these products can be a problem because QACs can irritate the respiratory tract, cause contact dermatitis, and initiate other inflammatory processes (Roberts, 2020; Heikaus, 2020).

There is a gap in the knowledge about the proper use and storage of disinfectants and hand sanitizers, especially among younger than older age groups and among Hispanic individuals compared to non-Hispanic individuals. It was reported a median knowledge score of 5.17 from a maximum of 9.0. This result demonstrated that an effective communication strategy is required to engage consumers in safety precautions (Gharpure et al., 2020).

Another concern about the increasing consumption of disinfectant products is their prolonged use. Routine evaluation of acute and chronic toxicity may not reveal the real impact of these compounds on the environment in a pandemic scenario. In fact, assessment needs to be adjusted to consider high-frequency exposure and cumulative toxicity. According to the European Union (EU) Regulation No 528/2012, specific ecotoxicological studies need to be performed to ensure that biocides are used safely. Classification for toxicity to aquatic organisms, short-term toxicity testing on fish and aquatic invertebrates, and bioaccumulation is necessary for these agents to be approved for consumption. To be registered with regulatory agencies, the process of disinfectant development considers the time of exposure and chronic toxicity. Still, the tests in the latter category only predict acute effects. Thus, even chronic tests have not been designed to evaluate the different types of exposure during a pandemic scenario (European Parliament and the Council of the European Union, 2012), which calls for the commercial availability of products with low environmental impact and negligible toxicity.

\section{QAC biodegradability and impact on aquatic life}

QACs can reach the aquatic environment through the discharge of WWTP into rivers, oceans, lakes, and estuaries or through the release of raw sewage. Anthropogenic activities, stormwater discharges, runoff and effluent discharge, are the leading cause of the presence of biocides in surface waters (Jardak et al., 2016). Therefore, the degradability of these compounds is essential to determine their accumulation in the environment.
QACs are usually biodegraded under aerobic conditions, and the biodegradation pathway starts with monooxygenations that depend on $\mathrm{O}_{2}$ and intracellular NADH (Lai et al., 2017). Aerobic QAC degradation is mainly attributed to the Xanthomonas, Aeromonas, and Pseudomonas species (Tezel \& Pavlostathis, 2015). Garcia et al. (2016) analyzed the biodegradability of five types of QAC-based gemini surfactants. The authors used a standard biodegradation test, the $\mathrm{CO}_{2}$ Headspace Test (OECD-310), to determine biodegradability. They determined the ultimate biodegradation or mineralization of the surfactants by evaluating the final inorganic products such as carbon dioxide and water. The results showed less than 5\% biodegradation after incubation for 28 days, with no differences between surfactants containing a hydrophobic or a hydrophilic spacer (Garcia et al., 2016).

QACs have biocide potential and can inhibit the microorganisms that degrade them. Nevertheless, in their review, DeLeo and colleagues (2020) reported that alkyl dimethyl benzyl ammonium chloride (ADBAC) and dialkyl dimethyl ammonium chloride (DADAC) are readily degradable. These authors showed that biodegradation varies from $72 \%$ to $100 \%$ and from $70 \%$ to $90 \%$ for ADBAC and DADAC, respectively, depending on the test used to evaluate degradation and chain length (DeLeo et al., 2020). The halflife for QAC hydrolysis is estimated at one year at $20^{\circ} \mathrm{C}$; a study with ADBAC determined that this compound is hydrolytically stable (ECHA, 2006 a).

Bioaccumulation depends on the physicochemical properties of the substance and biological features of organisms. QACs have a strong sorption affinity for different environmental materials, bacterial cell walls, and phospholipid bilayer membranes. It suggests that this type of substance can bioaccumulate when in contact with aquatic organisms (Timmer \& Droge, 2017; Groothuis et al., 2019). The ECHA registration dossier of dodecyl dimethyl ammonium chloride (DODAC) and alkyl dimethyl benzyl ammonium chloride (ADBAC) presented a bioconcentration factor (BCF) of $8,1 \times 107 \mathrm{mg} \mathrm{L}^{-1}$ and $7,9 \times 107 \mathrm{mg} \mathrm{L}^{-1}$ in bluegill fish (Lepomis macrochirus), respectively. However, the carbon chain residues were higher in the skin than in the edible tissues of the fish (ECHA, 2012, 2015). Kierkegaard and collaborators (2020) exposed rainbow trout (Oncorhynchus mykiss) to ten alkyl amines and two quaternary alkylammonium surfactants during seven days and reported that bioaccumulation could occur through sorption to external surfaces and systemic uptake. QACs had a higher accumulation in gills than in internal tissues; therefore, systemic uptake of alkylammonium surfactants appears to be very low (Kierkegaard et al., 2020).

QAC deposition in the aquatic environment is cause for concern, as summarized in Table 1. Five QACs, namely benzyl dimethyl dodecyl ammonium chloride (BAC-12), decyl trimethyl ammonium bromide (C10TAB), didecyl dimethyl ammonium chloride (DDAC), hexadecyl trimethyl ammonium chloride (ATAC-16), and tetradecyl trimethyl ammonium bromide $(\mathrm{C} 14 \mathrm{TAB})$, are hazardous to aquatic organisms. 
Table 1. Toxicity to aquatic organisms after QACs exposure. $\mathrm{IC}_{50}=$ Median Inhibition Concentration. Concentration to immobilize $50 \%$ of the population for Daphnia magna or concentration leading to $50 \%$ decrease in bioluminescence for Aliivibrio fischeri.

\begin{tabular}{|c|c|c|c|c|c|}
\hline $\begin{array}{l}\text { Quaternary ammonium } \\
\text { compound }\end{array}$ & $\begin{array}{l}\text { Concentration used } \\
\text { in exposure test }\end{array}$ & $\mathrm{IC}_{50}$ & $\begin{array}{l}\text { Other toxic effects caused on aquatic organ- } \\
\text { isms }\end{array}$ & $\begin{array}{l}\text { Log } \\
\text { Kow }\end{array}$ & References \\
\hline $\begin{array}{l}\text { Benzyl dimethyl do- } \\
\text { decyl ammonium chloride } \\
\text { (BAC-12) }\end{array}$ & $\begin{array}{c}0.004-25.0 \mathrm{mg} \mathrm{L}^{-1} \\
0.2-2.0 \mathrm{mg} \mathrm{L}^{-1}\end{array}$ & $\begin{array}{l}0.17 \pm 0.03 \mathrm{mg} \mathrm{L}^{-1} \\
\text { Aliivibrio fischeri } \\
0.6 \text { to } 1.1 \mathrm{mg} \mathrm{L}^{-1} \\
\text { D. magna }\end{array}$ & - & 2.93 & $\begin{array}{c}\text { (Di Nica et al., 2017) } \\
\text { (Garcia et al., 2016) } \\
\text { (ECHA, 2006) }\end{array}$ \\
\hline $\begin{array}{l}\text { Decyl trimethyl ammo- } \\
\text { nium bromide (C10TAB) }\end{array}$ & $\begin{array}{c}0.004-25.0 \mathrm{mg} \mathrm{L}^{-1} \\
0.2-2.0 \mathrm{mg} \mathrm{L}^{-1}\end{array}$ & $\begin{array}{l}\qquad 1 \mathrm{mg} \mathrm{L}^{-1} \\
\text { Aliivibrio fischeri }\end{array}$ & - & - & $\begin{array}{l}\text { (Di Nica et al., 2017) } \\
\text { (Garcia et al., 2016) }\end{array}$ \\
\hline $\begin{array}{l}\text { Didecyl dimethyl ammo- } \\
\text { nium chloride (DDAC) }\end{array}$ & $\begin{array}{c}0.004-25.0 \mathrm{mg} \mathrm{L}^{-1} \\
0.2-2.0 \mathrm{mg} \mathrm{L}^{-1} \\
0.4-2.0 \mathrm{mg} \mathrm{L}^{-1}\end{array}$ & $\begin{array}{l}0.40 \pm 0.06 \mathrm{mg} \mathrm{L}^{-1} \\
\text { Aliivibrio fischeri }\end{array}$ & $\begin{array}{l}\text { Increased mortality of larval walleye, lake } \\
\text { sturgeon, and northern pike }\end{array}$ & $\leq 3.0$ & $\begin{array}{c}\text { (Di Nica et al., 2017) } \\
\text { (Garcia et al.., 2016) } \\
\text { (Gray et al., 2005) } \\
\text { (ECHA, 2012) }\end{array}$ \\
\hline $\begin{array}{l}\text { Hexadecyl trimethyl } \\
\text { ammonium chloride } \\
\text { (ATAC-16) }\end{array}$ & $\begin{array}{c}0.004-25.0 \mathrm{mg} \mathrm{L}^{-1} \\
0.2-2.0 \mathrm{mg} \mathrm{L}^{-1}\end{array}$ & $\begin{array}{l}\quad<1 \mathrm{mg} \mathrm{L}^{-1} \\
\text { Aliivibrio fischeri }\end{array}$ & - & - & $\begin{array}{c}\text { (Di Nica v, 2017) } \\
\text { (Garcia et al., 2016) }\end{array}$ \\
\hline $\begin{array}{l}\text { Tetradecyl trimethyl } \\
\text { ammonium bromide } \\
\text { (C14TAB) }\end{array}$ & $\begin{array}{c}0.004-25.0 \mathrm{mg} \mathrm{L}^{-1} \\
0.2-2.0 \mathrm{mg} \mathrm{L}^{-1}\end{array}$ & $\begin{array}{l}\quad<1 \mathrm{mg} \mathrm{L}^{-1} \\
\text { Aliivibrio fischeri }\end{array}$ & - & - & $\begin{array}{l}\text { (Di Nica et al., 2017) } \\
\text { (Garcia et al., 2016) }\end{array}$ \\
\hline $\begin{array}{l}\text { Benzalkonium } \\
\text { chloride (BAC) }\end{array}$ & $\begin{array}{c}0.10-0.105 \mathrm{mg} \mathrm{L}^{-1} \\
0.18-0.324 \mathrm{mg} \mathrm{L}^{-1} \\
0.4 \mathrm{mg} \mathrm{L}^{-1} \\
0.1-5.0 \mathrm{mg} \mathrm{L}^{-1} \\
0.03 \mathrm{mg} \mathrm{L}^{-1}\end{array}$ & - & $\begin{array}{l}\text { Increased the acetilcholinesterase activity, } \\
\text { decreased the catalase activity, increased } \\
\text { the levels of thiobarbituric acid-reactive } \\
\text { substances, increased the GDI and the } \\
\text { erythrocytic nuclear abnormalities in rain- } \\
\text { bow trout. } \\
\text { Caused DNA damage in D. magna and C. } \\
\qquad \text { dubia } \\
\text { Reduced reproduction, germline toxicity } \\
\text { and increased the mortality in C. elegans. } \\
\text { Induced abnormal dorsal axons in fish } \\
\text { embryos. } \\
\text { Decrease in chlorophyll a concentrations in } \\
\text { I. galbana and C. gracilis culture. } \\
\text { I. galbana culture had a negative effect in } \\
\text { variable fluorescence. } \\
\text { Culture of C. gracilis showed a lower vari- } \\
\text { able fluorescence. }\end{array}$ & 2.88 & $\begin{array}{c}\text { (Antunes et al., 2016) } \\
\text { (Lavorgna et al., 2016) } \\
\text { (Pérez et al., 2009) } \\
\text { (Sreevidya et al., 2018) } \\
\text { (ECHA, 2006) }\end{array}$ \\
\hline
\end{tabular}

In acute exposure, almost all these QACs display $\mathrm{IC}_{50}$ (concentration leading to $50 \%$ decrease in bioluminescence) values below $1 \mathrm{mg} \mathrm{L}^{-1}$ against Aliivibrio fischeri. The most toxic are BAC-12 and DDAC, with $\mathrm{IC}_{50}$ of $0.17 \pm 0.03 \mathrm{mg} \mathrm{L}^{-1}$ and $0.40 \pm 0.06 \mathrm{mg} \mathrm{L}^{-1}$, respectively (Di Nica et al., 2017). A 48-hour immobilization test involving exposure of D. magna to QAC gemini surfactants afforded $\mathrm{IC}_{50}$ (concentration to immobilize $50 \%$ of the population in $48 \mathrm{~h}$ ) ranging from 0.6 to $1.1 \mathrm{mg} \mathrm{L}^{-1}$. In other words, these surfactants are very toxic to aquatic life (acute toxicity I) and toxic to aquatic life (acute toxicity II), respectively (Garcia et al., 2016).
DDAC acute toxicity has also been analyzed in three-dayold lake sturgeon (Acipenser fulvescens), walleye (Sander vitreus), and northern pike (Esox Lucius) larvae. At 0.4 to $0.8 \mathrm{mg} \mathrm{L}^{-1} \mathrm{DDAC}$, larval walleye and lake sturgeon mortality ranged from $0 \%$ to $100 \%$. At 0.8 to $2.0 \mathrm{mg} \mathrm{L}^{-1} \mathrm{DDAC}$, larval northern pike mortality varied from $0 \%$ to $100 \%$. The $\mathrm{LC}_{50} 96 \mathrm{~h}$ was $0.45,0.59$, and $1.04 \mathrm{mg} \mathrm{L}^{-1}$ for lake sturgeon, walleye, and northern pike, respectively. The concentration of 0.449 $\mathrm{L}^{-1}$ of DDAC was reported at stormwater discharge points, and the concentration decreased downstream the discharge site; DDAC is a biocide with high volume production and may 
be toxic to aquatic life (Gray et al., 2005; Hora et al., 2020). Although the presented data about QAC effects on bacteria, microcrustaceans and fish may indicate significant toxicity to aquatic organisms, data about acute, chronic, and cumulative toxicity lack in published studies.

BAC is a known QAC, and it is widely used both as a preservative and biocide in different formulations such as disinfectants and sanitizers (Choi et al., 2018). Antunes et al. (2016) verified alterations in rainbow trout (O. mykiss) chronically exposed to BAC concentrations $(0.100-1.050 \mathrm{mg}$ $\left.\mathrm{L}^{-1}\right)$. BAC concentrations as low as $0.180 \mathrm{mg} \mathrm{L}^{-1}$ increased acetylcholinesterase activity in the eyes of rainbow trout and decreased catalase activity in the liver and gills. At intermediate BAC concentrations $\left(0.180\right.$ and $\left.0.324 \mathrm{mg} \mathrm{L}^{-1}\right)$, the concentration of thiobarbituric acid reactive substances in the gill tissue increased. After the authors performed the comet assay on gill cells, they calculated a genetic damage index (GDI), which increased with rising BAC concentrations. Additionally, compared to the control group, erythrocytic nuclear abnormalities increased in fish exposed to BAC (Antunes et al., 2016).

Lavorgna et al. (2016) carried out acute exposure experiments on Daphnia magna and Ceriodaphnia dubia as models and found that BAC damaged DNA in both organisms and that the lowest levels of adverse effect emerged at $4 \times 10^{-7} \mathrm{mg}$ $\mathrm{L}^{-1} \mathrm{BAC}$ for D. magna and at $4 \times 10^{-6} \mathrm{mg} \mathrm{L}^{-1} \mathrm{BAC}$ for $C$. dubia. These concentrations are significantly lower, and raise concern about the aquatic impact of BAC (Lavorgna et al., 2016).

The toxicity of BAC to phytoplankton has already been described. Chlorophyll concentration in monoalgal cultures of Isochrysis galbana and Chaetoceros gracilis exposed to BAC decreased. Fluorescence measurements showed that I. galbana cultures exposed to $0,03 \mathrm{mg} \mathrm{L}^{-1} \mathrm{BAC}$ for $1,24,48,72$, or 96 $\mathrm{h}$ had less intense fluorescence, whereas the fluorescence of C. gracilis cultures was less affected by exposure to the same BAC concentration for 1 to $24 \mathrm{~h}$ (Pérez et al., 2009). Although these data could not explain the mechanisms through which BAC exerts genotoxicity, the use of this biocide and its release in the environment may impact aquatic life.

\section{Chlorhexidine (CHX)}

CHX effectively inactivates SARS-CoV-2 on surfaces and objects by interacting with cardiolipin in the virus membrane, thereby disintegrating the phospholipid bilayer of the virus and causing the cell to collapse (Cheung et al., 2012). CHX presents a no observed effect concentration (NOEC) for freshwater sediment of $2.44 \mathrm{mg} \mathrm{kg}^{-1}$, and no significant hydrolysis was reported after tests conducted during 5 days at $50^{\circ} \mathrm{C}$ in different $\mathrm{pH}$ values. The biodegradability of $\mathrm{CHX}$ was tested according to OECD TG 301D, and biodegradation was not observed under the test conditions. The bioconcentration factor of CHX is estimated at $42 \mathrm{~kg} \mathrm{~L}-1$, and biomagnification via aquatic organisms is not expected (ECHA, 2021).

Aquatic organisms have a different sensibility to toxicants. Therefore, to reduce flaws in ecotoxicity studies, organisms that represent multiple trophic levels must be considered when aquatic toxicity is assessed (Oliveira et al., 2018). Jesus and colleagues (2013) studied how CHX affected four organisms in an acute exposure study, the bacterium Aliivibrio fischeri, the crustacean Daphnia magna, the algae Pseudokirchneriella subcapitata, and the fish Danio rerio (embryos). On the basis of data regarding the effective concentration to eliminate $50 \%$ of the population $\left(\mathrm{EC}_{50}\right), \mathrm{CHX}$ was more toxic to the algae and crustacean $\left(\mathrm{EC}_{50} 72 \mathrm{~h}\right.$ was $0.062 \mathrm{mg} \mathrm{L}^{-1}$ and $\mathrm{EC}_{50} 48 \mathrm{~h}$ was 0.045 $\mathrm{mg} \mathrm{L}{ }^{-1}$, respectively) (Jesus et al., 2013).

For $P$. subcapitata, CHX induced growth inhibition in a dose-dependent manner in 72 hours of exposure. As for the fish embryos and the bacterium, $\mathrm{EC}_{50} 96 \mathrm{~h}$ was $0.804 \mathrm{mg} \mathrm{L}^{-1}$, and $\mathrm{EC}_{50} 15 \mathrm{~min}$ was $1.694 \mathrm{mg} \mathrm{L}^{-1}$, respectively. Sublethal effects were also analyzed, and feeding inhibition for D. magna was found at $\mathrm{EC}_{50} 6 \mathrm{~h}$ of $0.5037 \mathrm{mg} \mathrm{L}^{-1}$. CHX presented dose-response toxicity to fish embryos, altered the amniotic fluid with no teratogenic alterations, and caused early hatching at concentrations between 0.04 to $0.64 \mathrm{mg} \mathrm{L}^{-1}$. Analysis of enzymatic biomarkers in the Danio rerio embryos showed that cholinesterase induction increased after exposure to $\mathrm{CHX}$ at concentrations ranging from 0.08 to $0.9 \mathrm{mg} \mathrm{L}^{-1}$. CHX concentration at $0.9 \mathrm{mg} \mathrm{L}^{-1}$ induced catalase, but it did not affect lactate dehydrogenase or glutathione-S-transferase (Jesus et al., 2013).

\section{Povidone-iodine (PVP-I)}

PVP-I is a biocide commonly used in wound healing, mouth rinse, and aquacultures (Chen et al., 2018; Teixeira et al.., 2019). It has been demonstrated that PVP-I can inactivate SARS-CoV-2 on different surfaces (Chin et al.., 2020). Therefore, this biocide can enter the aquatic environment and is rapidly hydrolyzed, forming different ionic species. PVP-I is not likely to bioaccumulate in the environment, presenting an octanol/water partition coefficient ( $\log$ Kow) of 2.49 (ATSDR, 2004). Ecotoxicity information about PVP-I is available at the ECHA registration dossier. This document describes that this biocide presents short-term toxicity to fish (O. mykiss) and $D$. magna with $\mathrm{LC}_{50} 96 \mathrm{~h}$ of $1.67 \mathrm{mg} \mathrm{L}^{-1}$ and $\mathrm{LC}_{50} 48 \mathrm{~h}$ of $0.55 \mathrm{mg}$ $\mathrm{L}^{-1}$, respectively. PVP-I is also toxic to algae with $\mathrm{EC}_{50} 72 \mathrm{~h}$ of $0.13 \mathrm{mg} \mathrm{L}^{-1}$, and in chronic exposure condition, presents NOEC 72h of $0.025 \mathrm{mg} \mathrm{L}^{-1}$ (ECHA, 2019).

Hedayati and colleagues (2018) reported that acute PVP-I exposure to common carp (Cyprinus carpio) result in histological alterations in gill tissues, indicating damages in gills, such as bleeding, destruction of secondary lamellae, hyperplasia secondary blades, curvature second blade. Bleeding was observed in the lowest concentration $(5 \mathrm{mg}$ $\mathrm{L}^{-1}$ ). Degradation of gill tissue was observed in a doseresponse pattern in the concentrations of 5, 7, 8 and $9 \mathrm{mg} \mathrm{L}^{-1}$. In liver tissue, the lesions observed were bleeding, ascite, cell destruction and bile stagnation; these alterations increased in the highest concentration $\left(9 \mathrm{mg} \mathrm{L}^{-1}\right)$; however, the damages caused in the gill were more pronounced (Hedayati et al., 2018).

Fish gills are in direct and constant contact with the water; thus, the gill is the first target organ to water pollutants and 
is the entry site to toxicants. Therefore, gills are the primary site of toxic effects on the branchial epithelium (AbdelMoneim et al., 2012). The fish gill is a multifunctional organ important to respiration, osmoregulation, acid-base balance and nitrogenous waste excretion, and changes in this structure can lead to an imbalance of these functions. Further, it is commonly recognized that changes in fish gills indicate a response to environmental and chemical stressors (Au, 2004). On the other hand, the liver is an important organ for metabolization and has a key role in the bioaccumulation, biotransformation and excretion of contaminants in fish. Thus, changes in this organ can negatively impact these functions (Triebskorn et al., 2002).

Environmental studies describing PVP-I toxicity are still lacking; however, PVP-I is classified in the globally harmonized system of classification and labeling of chemicals (GHS) as toxic to aquatic life with long-lasting effects.

\section{Chloroxylenol (PCMX)}

PCMX presents log Kow of 3.27, and it is expected to be adsorbed in suspended solids and sediments. Estimated bioaccumulation of $66 \mathrm{mg} \mathrm{L}^{-1}$ was calculated using the $\log$ Kow, indicating that CHX has a moderate bioaccumulation capacity. Furthermore, less than $10 \%$ of $\mathrm{CHX}$ is hydrolyzed after 5 days at $50^{\circ} \mathrm{C}$, presenting a half-life higher than one year (ECHA, 2006 b).

Capkin et al. (2017) reported a chronic toxic effect of PCMX on rainbow trout. The comet assay revealed that exposure to $0.0042 \pm 0.9 \mathrm{mg} \mathrm{L}^{-1}$ PCMX for 40 days had a genotoxic effect on the DNA of red blood cells. Altered gene expression and histopathological lesions such as melanomacrophage center, necrosis, and pyknotic nucleus were also detected in gills, spleen, liver, and kidney trunk of rainbow trout. Abnormal behavior in the exposed animals was not observed in general, except the low feeding rate that was verified. PCMX presents genotoxicity for fish in chronic exposure, according to Comet assay with red blood cells of fish (Capkin et al., 2017).

Some studies compared the effects of PCMX and BAC on different aquatic organisms. At concentrations of 0.1 and $1 \mathrm{mg}$ $\mathrm{L}^{-1} \mathrm{BAC}$ reduced the reproduction of $C$. elegans from $163 \pm$ 7 to $106 \pm 9$ and $96 \pm 5$, respectively. PCMX at $1-10 \mathrm{mg} \mathrm{L}^{-1}$ also reduced the reproduction of C. elegans by $19-39 \%$ in a concentration-dependent manner and significantly decreased the lifetime of C. elegans from 15 days to 13.2 days. Exposure to PCMX also caused germline toxicity to C. elegans. As for the effects of PCMX or BAC on zebrafish embryos, these biocides at 0.5 and $5 \mathrm{mg} \mathrm{L}^{-1}$, respectively, increased the mortality rate. BAC did not cause malformation in the embryos, but PCMX caused pericardial edema and malformation, such as body curvatures in embryos after 72 hours post-fertilization. Moreover, exposure to $0.1 \mathrm{mg} \mathrm{L}^{-1}$ BAC induced abnormal dorsal axons in approximately $47 \%$ of the analyzed embryos. Embryos with body curvature malformation exposed to PCMX had more abnormal axons projections than embryos without this malformation (Sreevidya et al., 2018).
Data regarding non-QAC biocides effects on aquatic organisms are summarized in Table 2. On the basis of the data described in this review, the aquatic effects of biocides increase in the following order (from the least to the most toxic): CHX $<$ PVP-I $<$ PCMX $<$ QACs. Furthermore, it is still a challenge to evaluate the real hazard of chemicals, such as the biocides cited, due to the limitation of amount, quality and type of toxicity information of these and other substances (Dellarco et al., 2010).

\section{Greener and safer alternatives}

Concerns about the undesirable effects of chemicals on the environment, as well as the increasing demand of consumers for safe and ecological products, have resulted in the active engagement of industry and authorities in the promotion of safer products. Therefore, several safer chemical programs were recently launched in the US and $\mathrm{EU}$, identifying hazardous chemicals and listing chemicals among the safest for functional use (Nonino et al., 2021, accepted for publication).

For QAC-based disinfectants, although ecological alternatives can be found, they are still limited. Among the alternatives, accelerated hydrogen peroxide has been reported as an effective antimicrobial and fully degradable in the environment (Omidbakhsh, 2014). Another solution is to use free-rising water cleaners that are equally effective as a disinfectant but are environmentally friendly since chemical residues do not have the potential to accumulate (Rai et al., 2020).

It is essential to look for ecolabels on the disinfectant's package. These labels ensure that the product is environmentally friendly. US EPA manages the Safer Choice program, which certifies products that contain safer ingredients. For antimicrobial products like disinfectants and sanitizers, EPA offers the Design for Environment (DfE) label (US EPA, 2020a). However, purchasers that want to acquire safer products need to be aware that there are cautions and limits about certifications - not all are created equal, and "greenwashing" can happen when some certifications declare with little or no transparent information that the products are safer or less toxic to the human health and/or the environment. Credible certifications are usually made by an accredited independent third party. The standards have to be clear and publicly available and must include criteria that require the lab results, assessment of the ingredients to ensure safety individually and in mixtures, and auditing of the production process. Finally, the lack of ecolabels does not mean that the product is toxic to the environment. There are safer products that have not gone through a certification process, or the product can be new and not have received the certification yet (Perlmutter, 2015).

US EPA recommends giving preference to products with minimal presence of harmful chemicals, such as corrosive or irritating substances, substances classified as carcinogens or reproductive toxicants, ozone-depleting compounds, 
Table 2. Comparison of non-QAC biocides effects in aquatic organisms. $\mathrm{EC}_{50}=$ Median Effective Concentration to eliminate $50 \%$ of the population; $\mathrm{LC}_{50}=$ lethal concentration in $50 \%$ of the population.

\begin{tabular}{|c|c|c|c|c|c|}
\hline Biocide & $\begin{array}{c}\text { Concentration used } \\
\text { in exposure test } \\
0.0042 \pm 0.9 \mathrm{mg} \mathrm{L}^{-1} \\
1.0-10.0 \mathrm{mg} \mathrm{L}^{-1} \\
0.5 \mathrm{mg} \mathrm{L}^{-1}\end{array}$ & $\mathrm{EC}_{50} / \mathrm{LC}_{50}$ & $\begin{array}{l}\text { Other toxic effects caused on aquatic } \\
\text { organisms } \\
\text { Genotoxic activity, histopathological } \\
\text { lesions, melanomacrophage center, } \\
\text { necrosis, and pyknotic nucleus in } \\
\text { rainbow trout. } \\
\text { Reduced the reproduction, germline } \\
\text { toxicity and increased the mortality } \\
\text { of C. elegans. } \\
\text { Pericardial edema and body curva- } \\
\text { tures and abnormal axons projections } \\
\text { in zebrafish embryos. } \\
\text { DNA damage in D. magna and C. } \\
\text { dubia. }\end{array}$ & $\begin{array}{l}\text { Log } \\
\text { Kow }\end{array}$ & $\begin{array}{l}\text { Rererences } \\
\text { (Capkin et al., 2017) } \\
\text { (Sreevidya et al., 2018). } \\
\text { (ECHA registration dossier) }\end{array}$ \\
\hline
\end{tabular}

regulated hazardous materials, and chemicals designated as pollutants. Purchase products from renewable resources, including bio-based solvents from citrus, seed, vegetables, and pine oils, is preferable. Also, highly biodegradable and fragrance-free products with low flammability, low toxicity to aquatic species, and $\mathrm{pH}$ closer to neutral should be preferred (US EPA, 2020a).

Besides that, regarding disinfection as a protective measure against SARS-CoV-2, Green Seal recommends choosing US EPA List $\mathrm{N}$ products with one of the following ingredients: hydrogen peroxide, citric acid, lactic acid, ethyl alcohol (also called ethanol or just alcohol), isopropyl alcohol, peroxyacetic acid, or sodium bisulfate, which are safer options to mitigate SARS-CoV-2 spread (Green Seal, 2020). ECHA also has a list of active substances and products approved for disinfection. The ECHA biocides list considers the environmental impact caused by the disinfection measures. Thus, biocides listed by ECHA seem to be less harmful to the environment and verifying this list before acquiring a product will help select safer disinfectants for the environment. Also, following the labeling instruction of use and disposal is extremely important for the correct use of disinfectants, preventing undesirable effects on the environment (ECHA, 2020).

Although US EPA and ECHA provide information to influence consumers' choices for disinfectant products during the COVID-19 pandemic, there is still a need to develop/ discover novel disinfectants from renewable sources with higher biodegradability and lower quality ecotoxicity; thus, safer and greener than the conventional disinfectant products.

\section{CONCLUSION}

Cleaning and disinfection of frequently touched surfaces are recommended measures to prevent transmission of SARS- 
$\mathrm{CoV}-2$; however, awareness of the impact of the excessive use of biocides is needed. QAC-based disinfectants may be effective against viruses and other microorganisms, but the underlying negative impact in the aquatic environment must be considered. Overall, QACs can present genotoxicity to fish (rainbow trout) and significantly impact the mortality rate of different fish species. CHX increased feed inhibition of $D$. magna and negatively affected fish embryos. PVP-I caused damages on gill and liver of fish (common carp), and PCMX induced malformations in zebrafish embryos and decreased the reproduction of $C$. elegans. Future concerns include overusing biocides that may be genotoxic and mutagenic to aquatic organisms. Therefore, choosing biocides listed by ECHA and US EPA list $\mathrm{N}$ with minimal aquatic impact can be a tool to minimize these effects. Giving preference to accelerated hydrogen peroxide, free-rising water cleaners and products of renewable resources over QACs, CHX, PCMX and PVP-I would also be helpful to mitigate aquatic toxicity. In the future, we expect that disinfectants will have long-term effectiveness, higher biodegradability, and minor environmental effects.

\section{REFERENCES}

ABDEL-MONEIM AM, Al-KAHTANI MA, EELMENSHAWY OM. 2012. Histopathological biomarkers in gills and liver of Oreochromis niloticus from polluted wetland environments, Saudi Arabia. Chemosphere. 88(8):1028-1035. doi:10.1016/j. chemosphere.2012.04.001. chemosphere.2012.04.001.

ANTUNES SC, NUNES B, RODRIGUES S, NUNES R, FERNANDES J, CORREIA AT. 2016. Effects of chronic exposure to benzalkonium chloride in Oncorhynchus mykiss: Cholinergic neurotoxicity, oxidative stress, peroxidative damage and genotoxicity. Environ Toxicol Pharmacol. 45:115-122. doi:10.1016/j.etap.2016.04.016. https://doi.org/10.1016/j. etap.2016.04.016.

AU DWT. 2004. The application of histo-cytopathological biomarkers in marine pollution monitoring: A review. Mar Pollut Bull. 48(910):817-834. https://doi.org/10.1016/j.marpolbul.2004.02.032.

BLOOMFIELD SF, AIELLO AE, COOKSON B, O'BOYLE C, LARSON EL. 2007. The effectiveness of hand hygiene procedures in reducing the risks of infections in home and community settings including handwashing and alcohol-based hand sanitizers. Am J Infect Control. 35(10 SUPPL. 1). https:// doi.org/10.1016/j.ajic.2007.07.001.

CAPKINE, OZCELEPT,KAYIS S, ALTINOKI.2017. Antimicrobial agents, triclosan, chloroxylenol, methylisothiazolinone and borax, used in cleaning had genotoxic and histopathologic effects on rainbow trout. Chemosphere. 182:720-729. https:// doi.org/10.1016/j.chemosphere.2017.05.093.

CENTERS FOR DISEASE CONTROL AND PREVENTION. 2013. Guideline for Disinfection and Sterilization in Healthcare Facilities, 2008; Miscellaneous Inactivating Agents. CDC website.(May):9-13. http://www.cdc.gov/hicpac/Disinfection Sterilization/10_0MiscAgents.html.

CHAN K-H, SRIDHAR S, ZHANG RR, CHU H, FUNG AY-F, CHAN G, CHAN JF-W, TO KK-W, HUNG IF-N, CHENG VC-C, et al. 2020. Factors affecting stability and infectivity of SARS-CoV-2. J Hosp Infect. doi:10.1016/j.jhin.2020.07.009. http://www.ncbi.nlm.nih.gov/pubmed/32652214.
CHEN X, LAI C, WANG Y, WEI L, ZHONG Q. 2018. Disinfection effect of povidone-iodine in aquaculture water of swamp eel (Monopterus albus). PeerJ. 2018(11):1-13. https://doi. org/10.7717/peerj.5523.

CHEUNG HY, WONG MMK, CHEUNG SH, LIANG LY, LAM YW, CHIU SK. 2012. Differential actions of chlorhexidine on the cell wall of bacillus subtilis and escherichia coli. PLoS One. 7(5). https://doi.org/10.1371/journal.pone.0036659.

CHIN AWH, CHU JTS, PERERA MRA, HUI KPY, YEN H-L, CHAN MCW, PEIRIS M, POON LLM. 2020. Stability of SARS-CoV-2 in different environmental conditions. The Lancet Microbe. 1(1):e10. doi:10.1016/s2666-5247(20)30003-3. https:// doi.org/10.1016/S2666-5247(20)30003-3.

CHOI SM, ROH TH, LIM DS, KACEW S, KIM HS, LEE BM. 2018. Risk assessment of benzalkonium chloride in cosmetic products. J Toxicol Environ Heal - Part B Crit Rev. 21(1):8-23. doi:10.1080/10937404.2017.1408552. https://doi.org/10.1080/1 0937404.2017.1408552.

de BRUIN YB, LEQUARRE AS, McCourt J, Clevestig P, Pigazzani F, Zare Jeddi M, Colosio C, Goulart M. 2020. Initial impacts of global risk mitigation measures taken during the combatting of the COVID-19 pandemic. Saf Sci. 128(January). https://doi. org/10.1016/j.ssci.2020.104773.

DELEO PC, HUYNH C, PATTANAYEK M, SCHMID KC, PECHACEK N. 2020. Assessment of ecological hazards and environmental fate of disinfectant quaternary ammonium compounds. Ecotoxicol Environ Saf. 206:111116. doi:10.1016/j.ecoenv.2020.111116. https://doi.org/10.1016/j. ecoenv.2020.111116.

DELLARCO V, HENRY T, SAYRE P, SEED J, BRADBURY S. 2010. Meeting the common needs of a more effective and efficient testing and assessment paradigm for chemical risk management. J Toxicol Environ Heal - Part B Crit Rev. 13(2-4):347-360. http://doi.org/10.1080/10937404.2010.483950.

DI NICA V, GALLET J, VILLA S, MEZZANOTTE V. 2017. Toxicity of Quaternary Ammonium Compounds (QACs) as single compounds and mixtures to aquatic non-target microorganisms: Experimental data and predictive models. Ecotoxicol Environ Saf. 142(January):567-577. doi:10.1016/j.ecoenv.2017.04.028. http://doi.org/10.1016/j.ecoenv.2017.04.028.

ECHA. 2006a. Quaternary ammonium compounds , diC16-18- alkyldimethyl , chlorides Registration Dossier. 2006(1907):92129.

ECHA. 2006b. Chlorexylenol Registration Dossier. 712(1907):2006. ECHA. 2019. Povidone-Iodine Registration Dossier. 970:4-9.

ECHA. 2020. COVID-19 information Helping biocides companies and authorities. :1-4.

ECHA. 2021. Chlorexidine Registration Dossier. :2021.

EUROPEAN PARLIAMENT AND THE COUNCIL OF THE EUROPEAN UNION. 2012. REGULATION (EU) No 528/2012 OF THE EUROPEAN PARLIAMENT AND OF THE COUNCIL of 22 May 2012 concerning the making available on the market and use of biocidal products. Off $\mathrm{J}$ Eur Union. (L167):1-123. http://eur-lex.europa.eu/LexUriServ/LexUriServ. do?uri=OJ:L:2012:167:0001:0123:EN:PDF.

GARCIA MT, KACZEREWSKA O, RIBOSA I, BRYCKI B, MATERNA P, DRGAS M. 2016. Biodegradability and aquatic toxicity of quaternary ammonium-based gemini surfactants: Effect of the spacer on their ecological properties. Chemosphere. 154:155-160. https://doi.org/10.1016/j. chemosphere.2016.03.109.

GHARPURE R, MILLER GF, HUNTER CM, SCHNALL AH, KUNZ J, GARCIA-WILLIAMS AG. 2020. Safe Use and Storage of Cleaners, Disinfectants, and Hand Sanitizers: Knowledge, 
Attitudes, and Practices among U.S. Adults during the COVID-19 Pandemic, May 2020. Am J Trop Med Hyg. 104(May 2020):496501. https://doi.org/10.4269/ajtmh.20-1119.

GOLDMAN E. 2020. Exaggerated risk of transmission of COVID-19 by fomites. Lancet Infect Dis. 20(8):892-893. doi:10.1016/ S1473-3099(20)30561-2. http://dx.doi.org/10.1016/S14733099(20)30561-2.

GRAY MA, PEAKE SJ, FARRELL AP, BRUCH R. 2005. Acute didecyl dimethyl ammonium chloride toxicity to larval lake sturgeon, Acipenser fulvescens rafinesque, walleye Sander vitreus mitchill, and northern pike, Esox lucius linnaeus. Bull Environ Contam Toxicol. 75(5):890-896. https://doi. org/10.1007/s00128-005-0833-6.

GREEN SEAL. 2020. Guidelines for Safer COVID-19 Cleaning and Disinfection.

GROOTHUIS FA, TIMMER N, OPSAHL E, NICOL B, DROGE STJ, BLAAUBOER BJ, KRAMER NI. 2019. Influence of in Vitro Assay Setup on the Apparent Cytotoxic Potency of Benzalkonium Chlorides. Chem Res Toxicol. 32(6):1103-1114. https://doi.org/10.1021/acs.chemrestox.8b00412.

HEDAYATI A, DARABITABAR F, BAGHERI T, HEDAYATI ES, VAN DOAN H. 2018. Histopathological impairment of common carp (Cyprinus carpio) induced through povidoneiodine exposure. Microsc Res Tech. 81(11):1257-1260. https:// doi.org/10.1002/jemt.23131.

HEIKAUS CC. 2020. Hard surface cleaners during COVID-19. Novozymes.: $1-4$.

HORA PI, PATI SG, MCNAMARA PJ, ARNOLD WA. 2020. Increased Use of Quaternary Ammonium Compounds during the SARS-CoV-2 Pandemic and Beyond: Consideration of Environmental Implications. Environ Sci Technol Lett. 7(9):622-631. https://doi.org/10.1021/acs.estlett.0c00437.

JARDAK K, DROGUI P, DAGHRIR R. 2016. Surfactants in aquatic and terrestrial environment: occurrence, behavior, and treatment processes. Environ Sci Pollut Res. 23(4):3195-3216. https://doi. org/10.1007/s11356-015-5803-x.

JESUS FT, OLIVEIRA R, SILVA A, CATARINO AL, SOARES AMVM, NOGUEIRA AJA, DOMINGUES I. 2013. Lethal and sub lethal effects of the biocide chlorhexidine on aquatic organisms. Ecotoxicology. 22(9):1348-1358. https://doi. org/10.1007/s10646-013-1121-6.

KASPRZYK-HORDERN B, DINSDALE RM, GUWY AJ. 2009. The removal of pharmaceuticals, personal care products, endocrine disruptors and illicit drugs during wastewater treatment and its impact on the quality of receiving waters. Water Res. 43(2):363380. https://doi.org/10.1016/j.watres.2008.10.047. http://dx.doi. org/10.1016/j.watres.2008.10.047.

LAI YJS, ONTIVEROS-VALENCIA A, ILHAN ZE, ZHOU Y, MIRANDA E, MALDONADO J, KRAJMALNIK-BROWN R, RITTMANN BE. 2017. Enhancing biodegradation of C16alkyl quaternary ammonium compounds using an oxygenbased membrane biofilm reactor. Water Res. 123:825-833. doi:10.1016/j.watres.2017.07.003. http://dx.doi.org/10.1016/j. watres.2017.07.003.

LAVORGNA M, RUSSO C, D'ABROSCA B, PARRELLA A, ISIDORI M. 2016. Toxicity and genotoxicity of the quaternary ammonium compound benzalkonium chloride (BAC) using Daphnia magna and Ceriodaphnia dubia as model systems. Environ Pollut. 210:34-39. https://doi.org/10.1016/j.envpol.2015.11.042. http://dx.doi.org/10.1016/j.envpol.2015.11.042.

LI X, BROWNAWELL BJ. 2010. Quaternary ammonium compounds in urban estuarine sediment environments - A class of contaminants in need of increased attention? Environ Sci Technol. 44(19):7561-7568. https://doi.org/10.1021/es1011669.
NABI G, WANG Y, HAO Y, KHAN S, WU Y, LI D. 2020. Massive use of disinfectants against COVID-19 poses potential risks to urban wildlife. Environ Res. 188(May):9-11. https://doi. org/10.1016/j.envres.2020.109916.

NONINO ACW, DE OLIVEIRA JBV, MARQUES LP, et al. 2020. Aquatic environmental impact of cosmetics. Accepted to publication in the international book "Handbook of cosmetic science and technology" CRC press $5^{\text {th }}$ edition.

NOVOZYMES AND CONJOINT.LY. 2020. US consumers changed habits more than UK during COVID-19 The impact of COVID-19 on household cleaning. :1-8.

OGILVIE BH, SOLIS-LEAL A, LOPEZ JB, POOLE BD, ROBISON RA, BERGES BK. 2020. Alcohol-free hand sanitizer and other quaternary ammonium disinfectants quickly and effectively inactivate SARS-CoV-2. J Hosp Infect. 108:142 145. doi:10.1016/j.jhin.2020.11.023. https://doi.org/10.1016/j. jhin.2020.11.023.

OLIVEIRA GAR DE, LEME DM, DE LAPUENTE J, BRITO LB, PORREDÓN C, RODRIGUES L DE B, BRULL N, SERRET JT, BORRÀS M, DISNER GR, et al. 2018. A test battery for assessing the ecotoxic effects of textile dyes. Chem Biol Interact. 291(June):171-179. https://doi.org/10.1016/j.cbi.2018.06.026. https://doi.org/10.1016/j.cbi.2018.06.026.

OMIDBAKHSH N. 2014. Green and Safe Disinfectants, Can These Terms Really Coexist? Am J Infect Control. 42(6):S38-S39. https://doi.org/10.1016/j.ajic.2014.03.105.

ÖSTMAN M, LINDBERG RH, FICK J, BJÖRN E, TYSKLIND M. 2017. Screening of biocides, metals and antibiotics in Swedish sewage sludge and wastewater. Water Res. 115:318-328. https:// doi.org/10.1016/j.watres.2017.03.011.

PEREIRA BB. 2020. Challenges and cares to promote rational use of chloroquine and hydroxychloroquine in the management of coronavirus disease 2019 (COVID-19) pandemic: a timely review. J Toxicol Environ Heal - Part B Crit Rev. 23(4):177181. doi:10.1080/10937404.2020.1752340. https://doi.org/10.10 80/10937404.2020.1752340.

PÉREZ P, FERNÁNDEZ E, BEIRAS R. 2009. Toxicity of benzalkonium chloride on monoalgal cultures and natural assemblages of marine phytoplankton. Water Air Soil Pollut. 201(1-4):319-330. https://doi.org/10.1007/s11270-008-9947-x.

PERLMAN S. 2020. Another decade, Another coronavirus. N Engl J Med. 382(8):758-760. https://doi.org/10.1056/NEJMe1917479.

PERLMUTTER A. 2015. Advancing safer chemicals in products: The Key Role of Purchasing. Lowell Cent Sustain Prod UMass Lowell.:1-44. https://www.epa. gov/sites/production/files/2015-09/documents/uml-rpt_ greenpurchasing_7_15_14-2_0.pdf.

PRADHAN D, Biswasroy P, Kumar Naik P, Ghosh G, Rath G. 2020. A Review of Current Interventions for COVID-19 Prevention. Arch Med Res. 51(5):363-374. doi:10.1016/j.arcmed.2020.04.020. https://doi.org/10.1016/j.arcmed.2020.04.020.

RAI NK, Ashok A, Akondi BR. 2020. Consequences of chemical impact of disinfectants: safe preventive measures against COVID-19. Crit Rev Toxicol. 50(6):513-520. doi:10.1080/104 08444.2020.1790499. https://doi.org/10.1080/10408444.2020.1 790499.

ROBERTS C. 2020. Why Parents Should Be Cautious When Using Household Disinfectants. Consum Rep.:1-7. https:// www.consumerreports.org/cleaning/when-using-householddisinfectants-parents-should-be-cautious/.

SCHRANK CL, MINBIOLE KPC, WUEST WM. 2020. Are Quaternary Ammonium Compounds, the Workhorse Disinfectants, Effective against Severe Acute Respiratory Syndrome-Coronavirus-2? ACS Infect Dis. 6(7):1553-1557. 
https://doi.org/10.1021/acsinfecdis.0c00265.

DA SILVEIRA TEIXEIRA D, DE FIGUEIREDO MAZ, CHERUBINI K, DE OLIVEIRA SD, SALUM FG. 2019. The topical effect of chlorhexidine and povidone-iodine in the repair of oral wounds. A review. Stomatologija. 21(2):35-41.

SREEVIDYA VS, LENZ KA, SVOBODA KR, MA H. 2018. Benzalkonium chloride, benzethonium chloride, and chloroxylenol - Three replacement antimicrobials are more toxic than triclosan and triclocarban in two model organisms. Environ Pollut. 235:814-824. doi:10.1016/j.envpol.2017.12.108. https:// doi.org/10.1016/j.envpol.2017.12.108.

STATISTA. 2020. Effect of COVID-19 on disinfectant purchase behavior in the U . S . March 2020, by sex. 1(212):1-2.

TEZEL U, PAVLOSTATHIS SG. 2015. Quaternary ammonium disinfectants: Microbial adaptation,Degradation and ecology. Curr Opin Biotechnol. 33(Mic):296-304. doi:10.1016/j. copbio.2015.03.018. http://dx.doi.org/10.1016/j. copbio.2015.03.018.

THE NIELSEN COMPANY (US). 2020. Impacto Da Covid-19 Nas Vendas De Produtos De Giro Rápido No Brasil E Ao Redor Do Mundo. :7. https://www.mmaglobal.com/files/235._nielsen_-_ impactos_da_covid-19 nas_vendas_de produtos_de_consumo de_giro_raaipido_no_brasil_e_ao_redor_do_mundo.pdf.

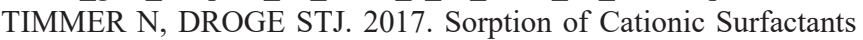
to Artificial Cell Membranes: Comparing Phospholipid Bilayers with Monolayer Coatings and Molecular Simulations. Environ Sci Technol. 51(5):2890-2898. https://doi.org/10.1021/acs. est.6b05662.

TRIEBSKORN R, ADAM S, CASPER H, HONNEN W, PAWERT M, SCHRAMM M, SCHWAIGER J, KÖHLER HR. 2002. Biomarkers as diagnostic tools for evaluating effects of unknown past water quality conditions on stream organisms. Ecotoxicology. 11(6):451-465. https://doi.org/10.1023/A:1021009418421.

US ENVIRONMENTAL PROTECTION AGENCY. 2020a. LongLasting SARS-Cov-2 Disinfection Evaluation Test Results Latest Test Results . 300(Atcc 15597):1-10. https://www.epa.gov/ healthresearch/long-lasting-sars-cov-2-disinfection-evaluationtest-results.

US ENVIRONMENTAL PROTECTION AGENCY. 2020b. LongLasting SARS-Cov-2 Disinfection Evaluation Test Results Latest Test Results . (Cdc):2-4. https://www.epa.gov/healthresearch/ long-lasting-sars-cov-2-disinfection-evaluation-test-results.
US ENVIRONMENTAL PROTECTION AGENCY. 2020c. LongLasting SARS-Cov-2 Disinfection Evaluation Test Results Latest Test Results . :1-5. https://www.epa.gov/healthresearch/ long-lasting-sars-cov-2-disinfection-evaluation-test-results.

US ENVIRONMENTAL PROTECTION AGENCY. 2020d. Identifying Greener Cleaning Products. :1-4.

US EPA. 2006. Reregistration Eligibility Decision for Alkyl Dimethyl Benzyl Ammonium Chloride (ADBAC). Fed Regist. (August):EPA739-R-06-009.

US EPA. 2020a. EPA Provides Consumers Additional Options for COVID-19 Disinfectants EPA has approved more than 460 products that are helping to reduce the spread of COVID-19. 2:1-2.

US EPA. 2020b. List N Tool: COVID-19 Disinfectants Feedback. :7-8.

VICENTE VA, LUSTOSA BPR, GRISOLIA ME, BEATO CP, BALSANELLI E, GUBERT FRUET V DE S, NOGUEIRA MB, RABONI SM, CARVALHO KAT, FLÔR IC, et al. 2021. Environmental detection of sars-cov-2 virus rna in health facilities in brazil and a systematic review on contamination sources. Int J Environ Res Public Health. 18(7). https://doi. org/10.3390/ijerph18073824.

VAN DE VOORDE A, LORGEOUX C, GROMAIRE MC, CHEBBO G. 2012. Analysis of quaternary ammonium compounds in urban stormwater samples. Environ Pollut. 164:150-157. doi:10.1016/j.envpol.2012.01.037. http://dx.doi. org/10.1016/j.envpol.2012.01.037.

VAN DOREMALEN N, BUSHMAKE T, MORRIS HD, HOLBROOK MD, GAMBLE A, BRANDI N, WILLIAMSON AT, HARCOURT JL, THORNBURG NJ, GERBER SI, LLOYD-SMITH JO, MUNSTER VJ. 2020. Aerosol and Surface Stability of SARS-CoV-2 as Compared with SARS-CoV-1. N Engl J Med.:0-3.

WHO. 2020. Coronavirus Disease 2019 (COVID-19) Situation Reports (World Health Organization,2020). 14(6):e01218.https:// www.who.int/emergencies/diseases/novel-coronavirus-2019/ situation-reports.

ZHANG C, CUI F, ZENG G MING, JIANG M, YANG Z ZHU, YU Z GANG, ZHU M YING, SHEN L QING. 2015. Quaternary ammonium compounds (QACs): A review on occurrence, fate and toxicity in the environment. Sci Total Environ. 518519:352-362. doi:10.1016/j.scitotenv.2015.03.007. http:// dx.doi.org/10.1016/j.scitotenv.2015.03.007. 